\title{
SISTEM INFORMASI TERINTEGRASI MONITORING , EVALUASI DAN PENGUSULAN SURAT KETERANGAN ONLINE AKADEMIK
}

\author{
Mokhamad Ramdhani Raharjo', ${ }^{1)}$ Fathur Rahman ${ }^{2)}$,Yusri Ikhwani ${ }^{3)}$ \\ ${ }^{1)}$ Fakultas Teknologi Informasi, Universitas Islam Kalimantan Muhammad Arsyad Al Banjari Banjarmasin \\ ramdhani@uniska-bjm.ac.id \\ ${ }^{2)}$ Fakultas Teknologi Informasi, Universitas Islam Kalimantan Muhammad Arsyad Al Banjari Banjarmasin \\ fathur243@gmail.com \\ ${ }^{3)}$ Fakultas Teknologi Informasi, Universitas Islam Kalimantan Muhammad Arsyad Al Banjari Banjarmasin \\ yusri@fti.uniska-bjm.ac.id
}

\begin{abstract}
ABSTRAK
Universitas Islam Kalimantan Muhammad Arsyad Al Banjari Banjarmasin merupakan Perguruan tinggi swasta di Kalimantan Selatan yang cukup besar dan bisa dipastikan juga memiliki jumlah mahasiswa yang banyak .Dengan jumlah mahasiswa yang banyak tidak menutup kemungkian terdapat permasalahan dari sisi profil data mahasiswa pada pada laman PDDIKTI, seperti kesalahan nama, tempat lahir atau jenis kesalahan lainya. Berdasarkan permasalahan tersebut bisa dipastikan terjadi antrian proses pengusulan serta terjadi kerumunan, ditambah lagi pada saat verifikasi data yudisium profil data diri mahasiswa wajib sesuai dengan data yang dijadikan acuan misalkan data ijazah terakhir terdapat banyak kesalahan. Berdasarkan permasalahan tersebut diperlukan sistem aplikasi pengajuan jenis kesalahan berbasis website yang dapat membantu proses pengajuan data kesalahan bagi mahasiswa tanpa perlu datang kekampus lagi karena disaat musim pandemi Covid-19 pemerintah pusat atau daerah melarang terjadinya kerumunan serta pembatasan kegiatan dilingkungan kampus guna mengurangi meluasnya wabah Covid-19 serta membantu pihak operator untuk verifikasi data ajuan lebih cepat. Pada penelitian ini mengembangkan aplikasi berbasis website untuk proses pengajuan kesalahan data PDDIKTI serta memonitoring dan verifikasi data ajuan dari admin operator. Beradasarkan hasil dari penelitian ini membantu Biro Akademik UNISKA MAB Banjarmasin dalam memproses data usulan pengajuan kesalahan PDDIKTI Mahasiswa.
\end{abstract}

Kata Kunci : Monitoring, Verifikasi, PDDIKTI, Pengajuan, Covid-19

\section{PENDAHULUAN}

Universitas Islam Kalimantan Muhammad Arsyad Al Banjari Banjarmasin merupakan salah satu universitas terbesar di Kalimantan Selatan. Pada tahun 2020 jumlah 20.791 mahasiswa pada awal semester ganjil 2020-2021 [1]. Dengan jumlah mahasiswa yang begitu banyak bisa dipastikan staff administrasi Biro Akademik akan tidak sanggup menangani pelayanan jika ada permasalahan data diri mahasiswa. Mengingat beberapa tahun terakhir banyak mahasiswa yang melakukan pengusulan perubahan data diri mahasiswa di laman PDDIKTI pada saat verifikasi data persyaratan yudisium yang dikarenakan tidak sesuai dengan identitas di Ijazah terakhir bagi mahsiswa aktif serta pengusulan perubahan data PDDIKTI bagi alumni untuk proses pendaftaraan CPNS atau keperluan lainya. Berdasarkan ajuan pengusulan perubahan data PDDIKTI yang cukup

Jurnal Ilmiah "Technologia" banyak terkadang membuat ruang pelayanan administrasi akdemik menjadi penuh sesak serta proses pelayanan membuat lambat karena harus mengantri lama. Apalagi diakhir tahun 2020 pandemi Covid 19 masih belum berakhir, ada larangan dari pemerintah pusat ataupun daerah untuk menghindari kerumunan masa serta penutupan sementara kegiatan di kampus sehingga membuat proses pengusulan perubahan data PDDIKTI menjadi terkendala dan menumpuk karena tidak ada sistem berbasis teknologi yang menangani hal tersebut karena selama ini proses pengajuan dilakukan secara konvensional dengan mengumpulkan berkas dan berkas tersebut nantinya akan dipindai serta diunggah di laman PDDIKTI. 


\begin{tabular}{|l|l|l|}
\hline & Informatika & \\
\hline TOTAL & 78 \\
\hline
\end{tabular}

Tabel 1. Jumlah Peserta Yudisium dan Kesalahan nama PDDIKTI tahun 2020

\begin{tabular}{|c|c|c|}
\hline No & Program Studi & $\begin{array}{l}\text { Jumlah } \\
\text { Kesalahan } \\
\text { PDDIKTI }\end{array}$ \\
\hline 1. & $\begin{array}{l}\text { S1-Kesehatan } \\
\text { Masyarakat }\end{array}$ & 13 \\
\hline $2 .$. & S1-Agribisnis & 2 \\
\hline 3. & S1-Peternakan & 2 \\
\hline 4. & S1-Manajemen & 10 \\
\hline 5. & $\begin{array}{l}\text { S1-Administrasi } \\
\text { Publik }\end{array}$ & 5 \\
\hline 6. & $\begin{array}{l}\text { S1-Ilmu } \\
\text { Komuniskasi }\end{array}$ & 2 \\
\hline 7. & $\begin{array}{l}\text { S1-Pendidikan } \\
\text { Kimia }\end{array}$ & 0 \\
\hline 8. & $\begin{array}{l}\text { S1-Pend. } \\
\text { Bimbingan dan } \\
\text { Konseling }\end{array}$ & 3 \\
\hline 9. & $\begin{array}{l}\text { S1-Pendidikan } \\
\text { Bahasa Inggris }\end{array}$ & 9 \\
\hline 10. & S1-Teknik Elektro & 1 \\
\hline 11. & S1-Teknik Mesin & 2 \\
\hline 12. & S1-Teknik Industri & 0 \\
\hline 13. & S1-Teknik Sipil & 1 \\
\hline 14. & S1-Hukum & 7 \\
\hline 15. & $\begin{array}{l}\text { S1-Ekonomi } \\
\text { Syariah }\end{array}$ & 1 \\
\hline 16. & $\begin{array}{l}\text { S1-Hukum } \\
\text { Ekonomi Syariah }\end{array}$ & 1 \\
\hline 17 & S2-Manajemen & 1 \\
\hline 18. & $\begin{array}{l}\text { S2-Ilmu } \\
\text { Komunikasi }\end{array}$ & 0 \\
\hline 19. & S1-Teknik & 18 \\
\hline
\end{tabular}

Berdasarkan data tersebut dapat dipastikan dapat menimbulkan antrian jika mahasiswa atau alumuni dating sekaligus untuk melakukan proses perubahan data.

.Penelitian ini menggunakan beberapa prosedur Analisa data untuk membuat sistem integrasi monitoring, evaluas dan pengusulan surat keterangan online supaya dalam pengembangan aplikasi tidak mengalami permasalahan.

sistem Informasi merupakan suatu kegiatan dari prosedur-prosedur yang diorganisasikan,bilamana dieksekusi akan menyediakan informasi untuk mendukung pengambilankeputusan dan pengendalian di dalam organisasi[2][3]. Dalam penelitian ini dilakukan beberapa prosedur Analisa data untuk pembuatan aplikasi sistem informasi surat keteangan online.

Penelitian yang dilakukan oleh Regita Ade irawan dan Eva Hani Fanida dengan judul Penerapan Electronic Government Melalui Sistem Layanan Surat Keterangan Elektronik (E-Suket) di Kelurahan Pojok Kecematan Mojoroto Kota Kediri menghasilkan sistem E-Suket dapat terintegrasi dengan aplikasi pelayanan warga lainnya yang ada di instansi pemerintah Kota Kediri sehingga pelayanan yang diberikan akan semakin efektif dan efisien[4].

Penelitian yang dilakukan oleh Maskur dan Muhammad Irfan dengan judul Pengembangan Sistem Informasi Manajemen Penelitian dan Pengabdian Kepada Masyarakat Fakultas Teknik (SIMTEK) menghasilkan sistem berbasis website yang dapat membantu tugas terhadap pegawai instansi tersebut dan mengavaluasi hasil dari kinerjanya[3].

Penelitian yang dilakukan oleh Inne Ajeng Kharismanande dan Eva Hany Fanida dengan judul Inovasi Pelayanan Kepolisian melalui Aplikasi Surat Keterangan Orang Terlantar (SKOT) Online di Sentra Pelayanan Kepolisian Terpadu (SPKT) Kepolisian Daerah Jawa Timur menghasil bahwa inovasi SKOT Online di SPKT Polda Jawa Timur masih sudah cukup baik namun belum maksimal karena masih ditemukannya masalah yang belum terselesaikan. Masalah tersebut dantaranya adalah digunakannya alamat web milik swasta, data EKTP yang belum dapat di akses, dan penggunaan 
internet sebagai sarana akses web tersebut masih dirasa kurang memadai[5].

Penelitian yang dilakukan oleh Gama Harta Nugraha Nur Raharyu dan Mahyar Zulfikar Dwiarto dengan judul Penjadwalan Proyek Penngadaan Perangkat SKCK (Surat Keterangan Catatan Kepolisian) Online Dengan Metode Critical Path Method di PT. XZY menyimpulkan bahwa Hasil perhitungan dengan metode CPM menunjukan bahwa waktu yang dibutuhkan untuk menyelesaikan proyek yaitu 91 hari kerja hal ini membuktikn metode CPM lebih efektif dan efiesien dalam membuat perencanaan waktu proyek[6]

Penelitian yang dilakukan oleh Teguh Setya Wiyono, Ragil Saputra dan Eko Adi Sarwoko dengan judul Sistem yang membantu permohonan pendaftaraan SIM secara online sehingga tidak terjadi antrian pada saat pembuatan SIM baru menghasilkan bahwa Sistem yang membantu permohonan pendaftaraan SIM secara online sehingga tidak terjadi antrian pada saat pembuatan SIM baru[7].

Penelitian yang dilakukan Djoko Sasono, Agus Darwanto dan Supardi dengan judul Administrasi Desa Online Desa Nogosari Kecamatan Ngadirojo Kabupaten Pacitan berdasarkan hasil penelitian yang dilakukan menunjukan bawah sistem administrasi online membantu bagi perangkat desa dalam penyelesaian permasalahan adminsitrasi dengan baik efektif dan efiesien[8].

Penelitian yang dilakukan oleh Muhammad Khafid dan Agus Wahyudin dengan judul Penyusunan dan implementasi sistem pelayanan 145omput surat pengantar RT/RW Online untuk mewujudkan Semarang "SMART CITY" menghasil Sistem aplikasi surat pengantar RT RW online yang disusun oleh tim pengabdi merupakan salah satu solusi pemberian pelayanan administrasi warga yang efektif, karena sistem ini bisa mengatasi beberapa permasalahan kesulitan warga dalam memperoleh layanan administrasi surat pengantar RT RW yang cepat dan tanpa batas daridimensi ruang dan waktu[9].

Sistem Informasi merupakan kombinasi dari teknologi informasi dan aktivitas orang yang menggunakan teknologi itu untuk mendukung operasi dan manajemen. Dalam arti yang sangat luas, istilah sistem informasi yang sering digunakan merujuk kepada interaksi antara orang, proses algoritmik, data, dan teknologi. Dalam pengertian ini, istilah ini digunakan untuk merujuk tidak hanya pada penggunaan organisasi teknologi informasi dan komunikasi (TIK), tetapi juga untuk cara di mana orang berinteraksi dengan teknologi Jurnal Ilmiah "Technologia" ini dalam mendukung proses bisnis. Ada membuat perbedaan yang jelas antara sistem informasi, dan komputer sistem TIK, dan proses bisnis. Sistem informasi yang berbeda dari teknologi informasi dalam sistem informasi biasanya terlihat seperti memiliki komponen TIK. Hal ini terutama berkaitan dengan tujuan pemanfaatan teknologi informasi. Sistem informasi juga berbeda dari proses bisnis. Sistem informasi membantu untuk mengontrol kinerja proses bisnis[10]

\section{METODE PENELITIAN}

Perancangan Sistem Informasi Terintegrasi Monitoring, Evaluasi dan Pengusulan Surat keterangan Online Akademik dilakukan setelah menganalisa data hasil survey dari lapangan dan juga studi literatur yang tersedia melalui beberapa tahapan seperti berikut:

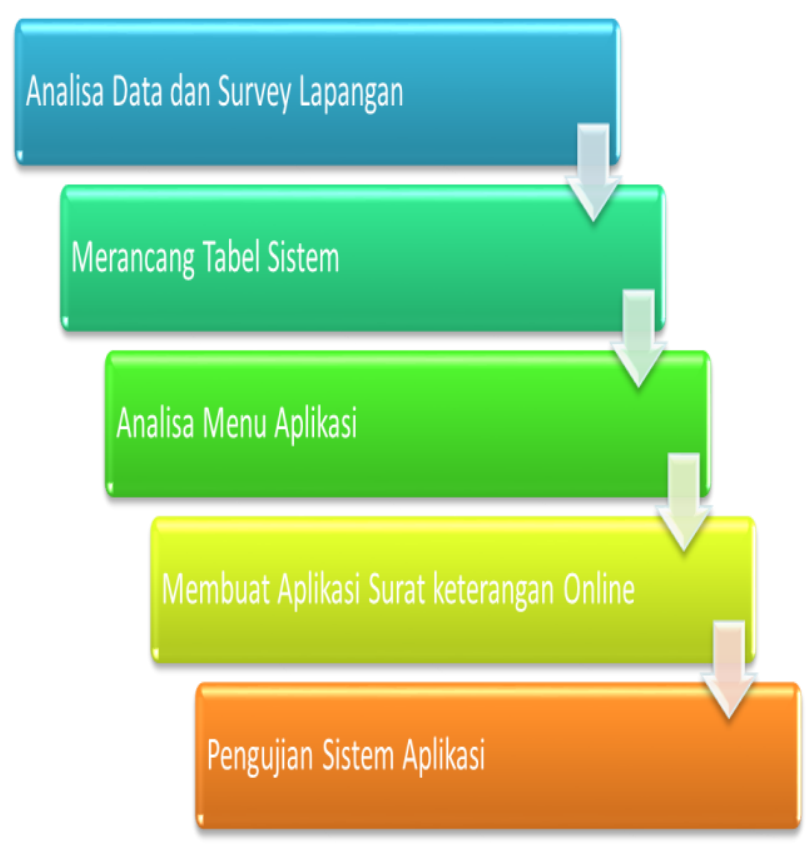

Gambar 1 metode penelitian

Beberapa tahapan yang dikerjakan dalam pengembangan Sistem Informasi Terintegrasi Monitoring, Evaluasi dan Pengusulan Surat keterangan Online Akademik:.

a) Analisis Data dan Survey Lapangan

Pada tahapan ini dilakukan Analisa dilapangan terhadap bukti dokumen yang diperlukan untuk proses upload berkas ajuan serta menganalisa sistem yang akan dikembangkan berdasarkan saran masukan dari mahasiswa yang nantinya menggunakan aplikasi. 
b) Merancangan Tabel Sisem

Pada tahapan ini melakukan proses pembuatan sistem basis data yang nantinya digunakan untuk menyimpan proses transaksi.

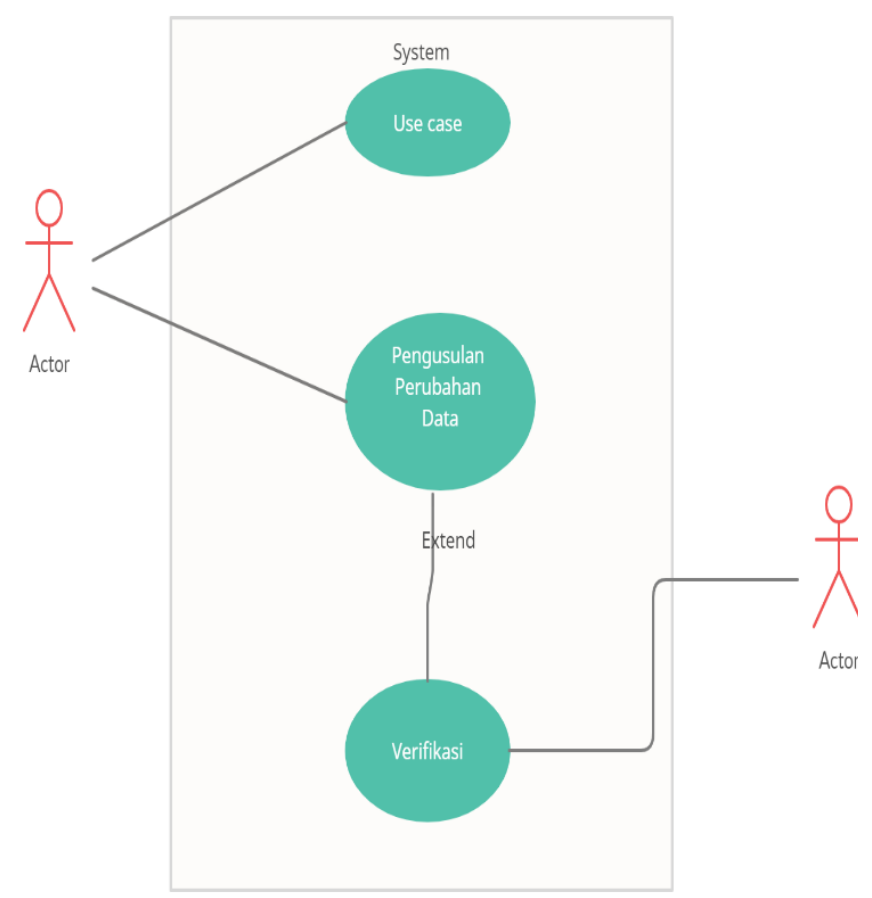

Gambar 2 Usulan Use Case Diagram

Pada Gambar 2 Use Case Diagram Sistem yang diusulkan, aktor yang terlibat dalam sistem yaitu Mahasiswa dan Operator. Aktor menggunakan sistem aplikasi sesuai pada alur yang dihubungkan pada rancangan Use Case. Aktor Mahasiswa melakukan proses pengajuan perubahan data pada sistem dan Aktor Operator digunakan untuk veridkasi data ajuan.

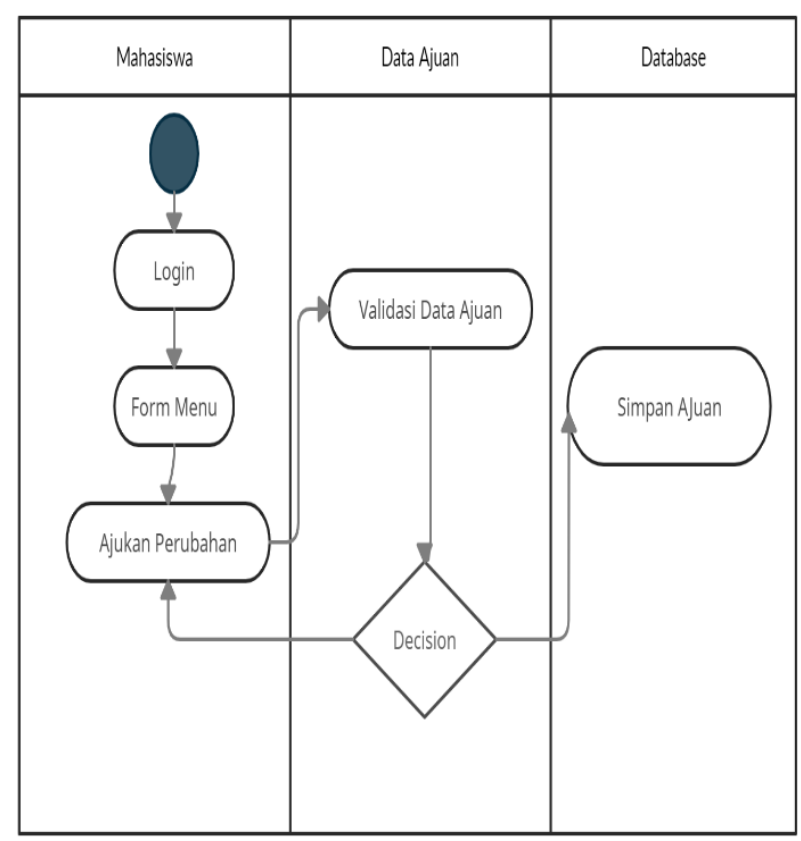

Gambar 3 Usulan Activity Diagram Pengajuan

Deskripsi Gambar 3 merupakan alur pengajuan perubahan data oleh user mahasiswa dengan melengkapi berkas yang diperlukan

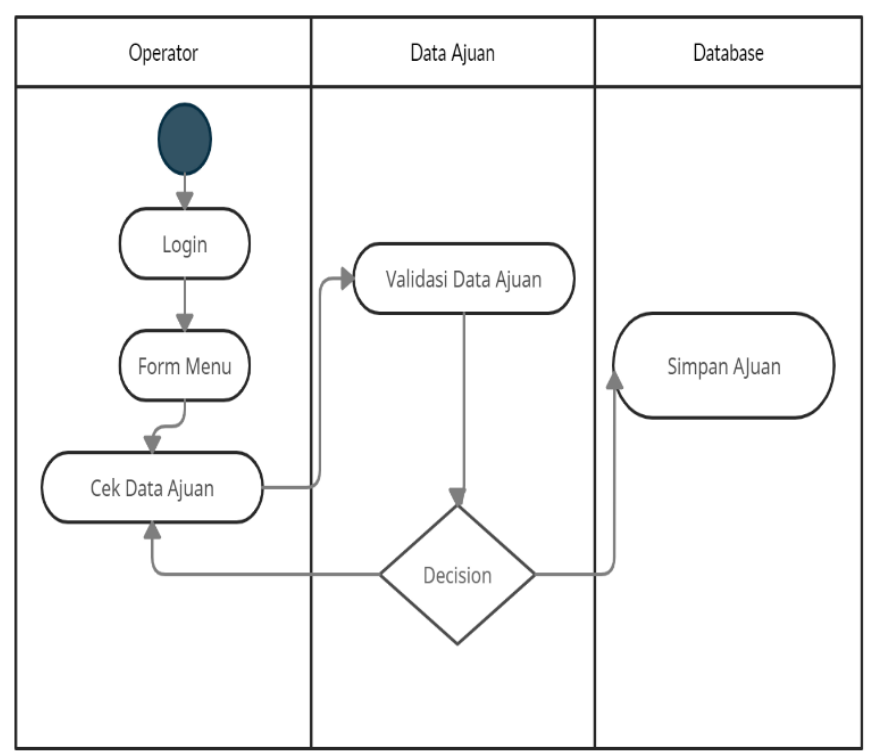

Gambar 4 Usulan Activity Diagram Verifikasi

Deskripsi Gambar 4 merupakan alur proses verifikasi data usulan pengajuan perubahan data oleh operator, apabila memenuhi persyaratan data ajuan diterima dan jika tidak memenuhi data ajuan dikembalikan.

c) Analisis Menu Aplikasi

Pada tahapan ini dilakukan desain menu aplikasi sesuai kebutuhan sistem dengan memperhatikan kemudahan dalam mengimplementasikannya. 
d) Pembuatan aplikasi

Pada tahan ini dilakuan proses pengkodingan atau pembuatan aplikasi berdasarkan alur bisnis aplikasi yang diperoleh saat survey lapangan.

e) Pengujian Sistem

Pada tahapan ini pengujian aplikasi menggunakan Blackbox Tesing dengan menguji fungsi-fungsi menu pada aplikasi.

\section{Tabel 1. Pengujuan Blackbox Testing}

\begin{tabular}{|c|c|c|c|}
\hline $\begin{array}{l}\text { Aktifitas } \\
\text { Pengujian }\end{array}$ & $\begin{array}{c}\text { Realisasi } \\
\text { yang } \\
\text { diharapkan }\end{array}$ & $\begin{array}{c}\text { Hasil } \\
\text { Pengujian }\end{array}$ & $\underset{\mathrm{n}}{\text { Kesimpula }}$ \\
\hline Login & $\begin{array}{l}\text { Halaman } \\
\text { Utama }\end{array}$ & $\begin{array}{l}\text { Tampil } \\
\text { Halaman } \\
\text { Utama }\end{array}$ & $\begin{array}{l}\mathrm{X}] \\
\text { Diterima }\end{array}$ \\
\hline $\begin{array}{l}\text { Simpan } \\
\text { Pengajuan } \\
\text { Kesalahan } \\
\text { Jenis } \\
\text { Kelamin } \\
\text { Simpan } \\
\text { Data } \\
\text { Pengajuan } \\
\text { kesalahan } \\
\text { nama, } \\
\text { tempat dan } \\
\text { tanggal lahir }\end{array}$ & $\begin{array}{l}\text { Menyimpan } \\
\text { Data ke } \\
\text { Database }\end{array}$ & $\begin{array}{l}\text { Data } \\
\text { tersimpan }\end{array}$ & $\begin{array}{l}{[\mathrm{X}]} \\
\text { Diterima }\end{array}$ \\
\hline $\begin{array}{l}\text { Menampilka } \\
\text { n data prodil }\end{array}$ & $\begin{array}{l}\text { Menampilka } \\
\text { n data }\end{array}$ & $\begin{array}{l}\text { Data } \\
\text { berhasil } \\
\text { ditampilka } \\
\text { n }\end{array}$ & $\begin{array}{l}{[\mathrm{X}]} \\
\text { Diterima }\end{array}$ \\
\hline $\begin{array}{l}\text { Pencarian } \\
\text { Data ajuan }\end{array}$ & $\begin{array}{l}\text { Menampilka } \\
\text { n data yang } \\
\text { dicari }\end{array}$ & $\begin{array}{l}\text { Data } \\
\text { berhasil } \\
\text { ditampilka } \\
\text { n }\end{array}$ & $\begin{array}{l}{[\mathrm{X}]} \\
\text { Diterima }\end{array}$ \\
\hline $\begin{array}{l}\text { Verifikasi } \\
\text { data } \\
\text { kesalahan } \\
\text { jenis } \\
\text { kelamin }\end{array}$ & $\begin{array}{l}\text { Tampil data } \\
\text { verifikasi } \\
\text { data jenis } \\
\text { kelamin }\end{array}$ & $\begin{array}{l}\text { Data } \\
\text { berhasil } \\
\text { diverifikas } \\
\text { i }\end{array}$ & $\begin{array}{l}{[\mathrm{X}]} \\
\text { Diterima }\end{array}$ \\
\hline $\begin{array}{l}\text { Verifikasi } \\
\text { data ajuan } \\
\text { kesalahan } \\
\text { nama, } \\
\text { tempat } \\
\text { tanggal lahir }\end{array}$ & $\begin{array}{l}\text { Tampil data } \\
\text { verifikasi } \\
\text { data ajuan }\end{array}$ & $\begin{array}{l}\text { Data } \\
\text { berhasil } \\
\text { diverifikas } \\
\text { i }\end{array}$ & $\begin{array}{l}{[\mathrm{X}]} \\
\text { Diterima }\end{array}$ \\
\hline
\end{tabular}

\section{HASIL DAN PEMBAHASAN}

Hasil pengembangan Sistem Informasi Terintegrasi Monitoring, Evaluasi dan Pengusulan Surat Keterangan Online Akademik.

\section{Antarmuka Halaman Utama}

Jurnal Ilmiah “Technologia”
Antarmuka Utama seperti yang ditampilkan pada Gambar 5 digunakan memilih menumenu yang akan dioperasikan.

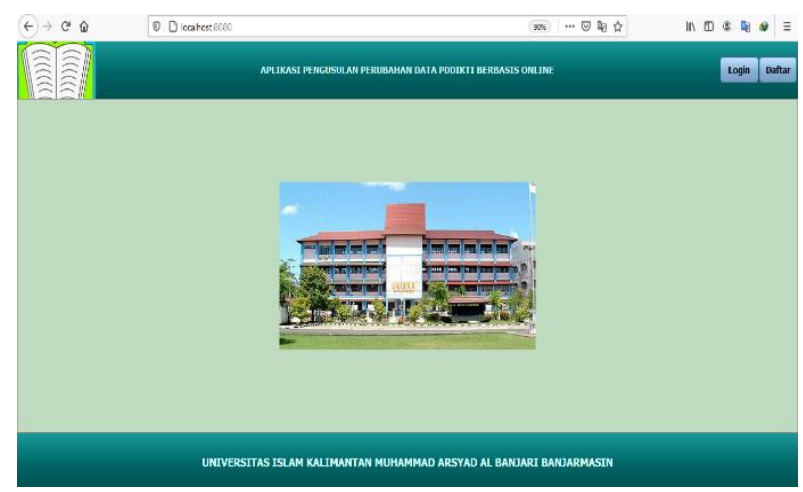

Gambar 5. Antarmuka Halaman Utama

2. Antarmuka Halaman Pendaftaran

Antarmuka Halaman Pendataran seperti yang ditampilkan pada Gambar 6 berfungsi membuat akun aplikasi agar bisa menggunakan aplikasi ini untuk proses pengajuan kesalahan data PPDIKTI.

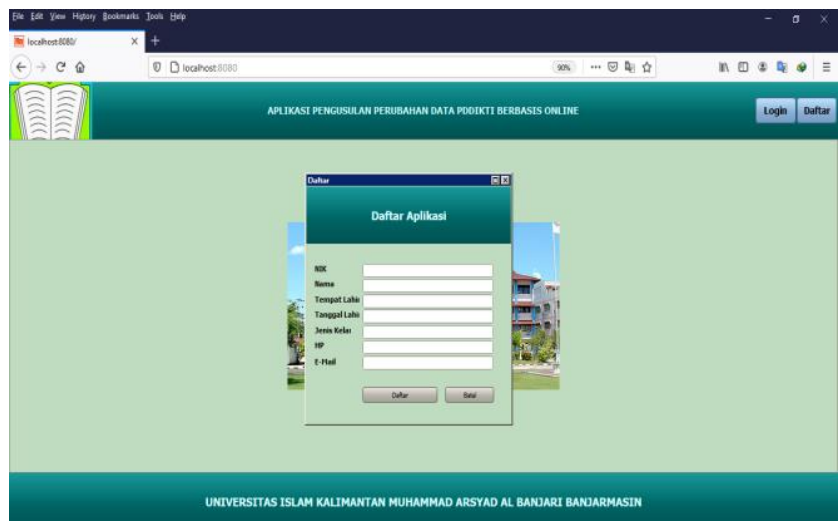

Gambar 6. Antarmuka Halaman Pendaftaran

3. Antarmuka Halaman Login

Antarmuka Data profil damkar yang ditampilkan pada Gambar 7 berfungsi login atau masuk kesistem aplikasi

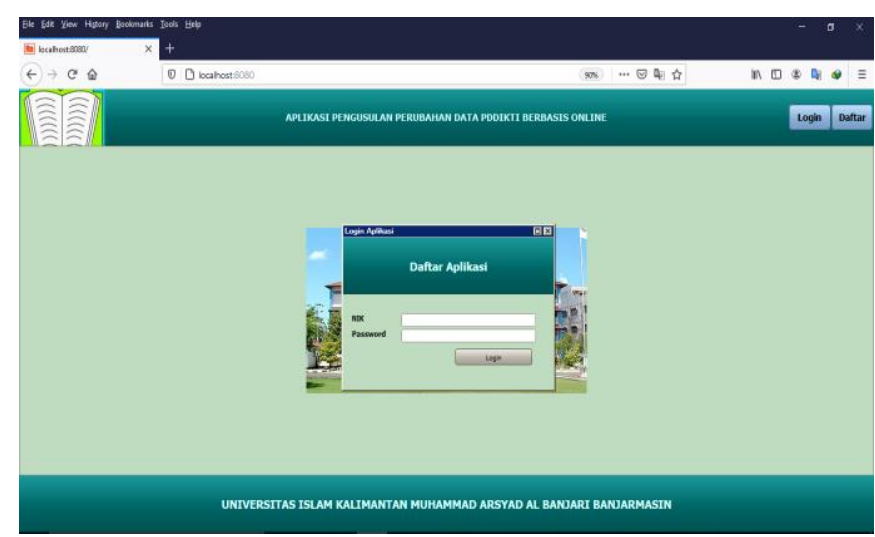

Gambar 7. Antarmuka Halaman Login 


\section{Antarmuka Halman Profil}

Antarmuka halaman profil seperti yang ditampilkan pada gambar 8 berfungsi untuk menyimpan data profil mahasiswa yang benar sesuai data diri yang nantinya digunakan seagai acuan pengusulan perubahan data.

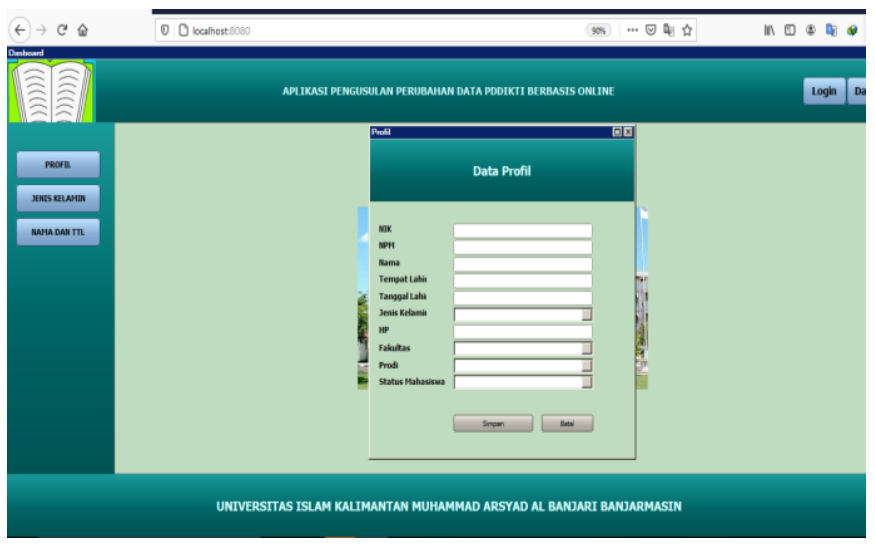

Gambar 8. Antarmuka Halaman Profil

5. Antarmuka halaman Ajuan Kesalahan Jenis Kelamin

Antarmuka halaman ajuan kesalahan jenis kelamin berfungsi untuk mengunngah berkas ajuan jenis kesalahan yang nantinya akan dilihat dan diverifikasi ajuan oleh operator seperti yang ditampilkan pada Gambar 9 .

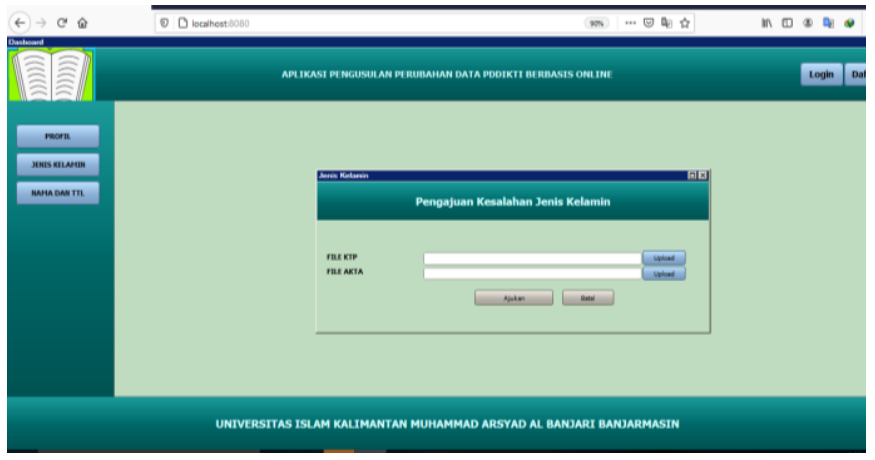

Gambar 9. Antarmuka Halaman Kesalahan jenis kelamin

6. Antarmuka Halaman pengajuan kesalahan nama, tempat dan tanggal lahir

Antarmuka halaman pengajuan kesalahan nama dan tempat tanggal lahir yang ditampilkan pada Gambar 10 berfungsi mengunggah beberapa berkas ajuan yang nantinya akan diverifikasi oleh operator

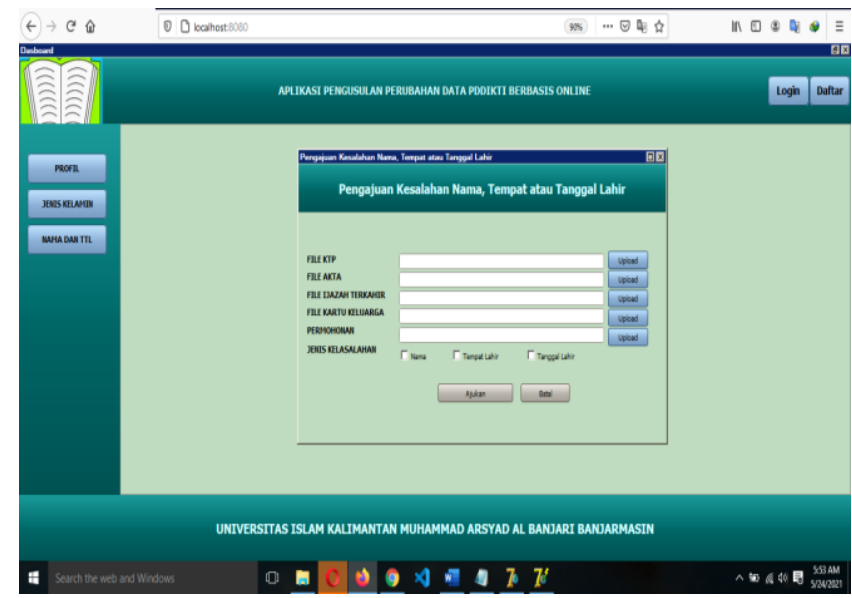

Gambar 10. Antarmuka Halaman Kesalahan nama dan tempat tanggal lahir

7. Antarmuka Halaman Operator

Antarmuka halaman operator seperti yang ditampilkan pada gambar 11 berfungsi untuk melihat data ajuan kesalahan dan memverifikasi data.

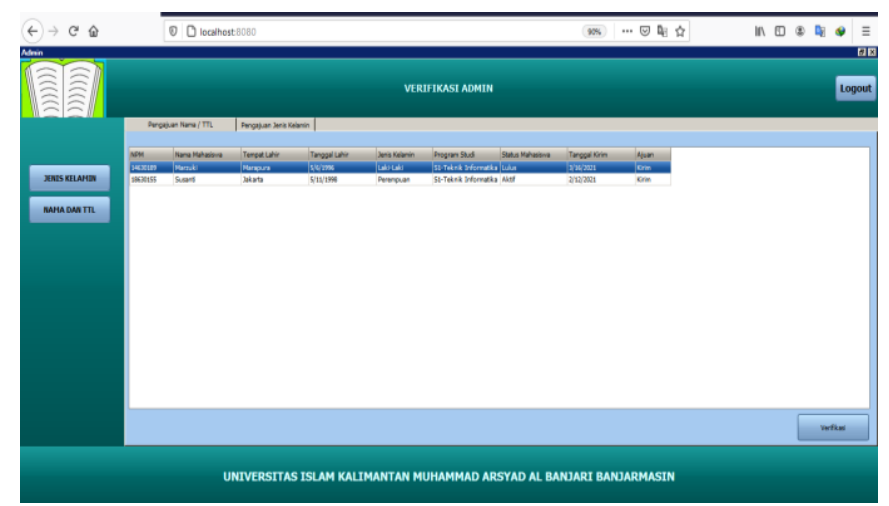

Gambar 11. Antarmuka Halaman Operator

\section{KESIMPULAN}

Dari hasil penelitian yang telah dilaksanakan disimpulkan sebagai berikut:

1. Proses monitoring serta verifikasi data ajuan kesalahan dapat dilakukan dengan baik.

2. Mahasiswa tidak perlu lagi dating ke kampus untuk pengusulan data kesalahan sehingga tidak terjadi kerumunan serta antrian.

\section{REFERENSI}

Jurnal Ilmiah “Technologia” 
[1] "No Title." https://pddikti.kemdikbud.go.id/ (accessed Nov. 28, 2020).

[2] P. D. Astuti, "Sistem Informasi Penjualan Obat Pada Apotek Jati Farma Arjosari," vol. 3, no. 4, pp. 34-39, 2011.

[3] Maskur and M. Irfan, "Pengembangan Sistem Informasi Manajemen Penelitian Dan Pengabdian Kepada Masyarakat Fakultas Teknik ( Simtek )," Semin. Nas. Teknol. dan Rekayasa, pp. 1-136, 2018.

[4] K. Elektronik et al., "PENERAPAN ELECTRONIC GOVERNMENT MELALUI SISTEM LAYANAN SURAT Regita Ade Irawan Abstrak," pp. 1-7, 2017.

[5] I. AJENG KHARISMANANDE and E. HANY FANIDA, "Inovasi Pelayanan Kepolisian Melalui Aplikasi Surat Keterangan Orang Terlantar (Skot) Online Di Sentra Pelayanan Kepolisian Terpadu (Spkt) Kepolisian Daerah Jawa Timur," Publika, vol. 7, no. 4, 2019.

[6] G. Rahayu and M. Z. Dwiarto, "Penjadwalan Proyek Pengadaan Perangkat SKCK (Surat Keterangan Catatan Kepolisian) Online Dengan Metode Critical Path Method di PT. XYZ," J. Ind. Serv., vol. 2, no. 2, pp. 214-223, 2017, [Online]. Available: http://jurnal.untirta.ac.id/index.php/jiss/arti cle/view/1533.

[7] A. Bardadi, M. A. Firdaus, and Firdaus, "Pengembangan Sistem Informasi Pendaftaran Surat Ijin Mengemudi Online," J. Sist. Inf., vol. 2, no. 1, pp. 169-178, 2010, [Online]. Available: http://ejournal.unsri.ac.id/index.php/jsi/arti cle/viewFile/719/261.

[8] D. Sasono, A. Darwanto, and Supardi, "Administrasi Desa Onlne Desa Nogosari Kecamatan Ngadirojo Kabupaten Pacitan," J. Pengabdi. LPPM Untag Surabaya, vol. 02, no. 01, pp. 85-90, 2016, [Online]. Available: http://jurnal.untagsby.ac.id/index.php/jpm17/article/viewFile/ 1035/923.

[9] M. Khafid and A. Wahyudin, "Penyusunan Dan Implementasi Sistem Pelayanan Publik Surat Pengantar Rt/ Rw Online Untuk Mewujudkan Semarang 'Smart City,'” Rekayasa, vol. 16, no. 2, pp. 209 218, 2019, doi: 10.15294/rekayasa.v16i2.17517.

[10] "Pengertian Sistem Informasi," 2020, [Online].Available:

Jurnal Ilmiah "Technologia"
https://id.wikipedia.org/wiki/Sistem_inform asi. 